\title{
A Gene Cluster Responsible for Alkylaldoxime Metabolism Coexisting with Nitrile Hydratase and Amidase in Rhodococcus globerulus A-4 ${ }^{\dagger}$,
}

\author{
Sheng-Xue Xie ${ }^{\S}$ Yasuo Kato, Hidenobu Komeda, Satoshi Yoshida, and Yasuhisa Asano* \\ Biotechnology Research Center, Faculty of Engineering, Toyama Prefectural University, \\ 5180 Kurokawa, Kosugi, Toyama 939-0398, Japan
}

Received June 25, 2003; Revised Manuscript Received August 26, 2003

\begin{abstract}
An enzyme "alkylaldoxime dehydratase (OxdRG)" was purified and characterized from Rhodococcus globerulus A-4, in which nitrile hydratase (NHase) and amidase coexisted with the enzyme. The enzyme contains heme $b$ as a prosthetic group, requires reducing reagents for the reaction, and is most active at a neutral $\mathrm{pH}$ and at around $30{ }^{\circ} \mathrm{C}$, similar to the phenylacetaldoxime dehydratase from Bacillus sp. OxB-1 (OxdB). However, some differences were seen in subunit structure, substrate specificity, and effects of activators and inhibitors. The corresponding gene, oxd, encoding a 1059-base pair ORF consisting of 353 codons, was cloned, sequenced, and overexpressed in Escherichia coli. The predicted polypeptide showed $30.3 \%$ identity to OxdB. The gene is mapped just upstream of the gene cluster encoding the enzymes involved in the metabolism of aliphatic nitriles, i.e., NHase and amidase, and their regulatory and activator proteins. We report here the existence of an aldoxime dehydratase genetically linked with NHase and amidase, and responsible for the metabolism of alkylaldoxime in $R$. globerulus.
\end{abstract}

Aldoximes derived from amino acids are considered to be intermediates in the biosynthesis of cyanogenic glucosides and glucosinolates in plants (1). However, information on aldoxime metabolism is quite limited and the genetics and enzymology have not been well characterized. One oximemetabolizing enzyme (cytochrome P450 CYP71E1) has been reported to catalyze the conversion of aldoxime to $\alpha$-hydroxynitrile in the pathway for biosynthesis of cyanogenic glucoside dhurrin in Sorghum bicolor (2-4). Other cytochrome P450s, namely, CYP83 homologues (A1 and B1), have also been identified as oxime-metabolizing enzymes, which catalyze the conversion of indoleacetaldoxime to the corresponding aci-nitro compound, the first step in the biosynthesis of indole glucosinolates in Arabidopsis thaliana. However, the level of activity is quite low, and the mechanisms involved have not been studied. Indoleacetaldoxime is known to be a metabolic branch point between the production of indoleacetic acid and indole glucosinolates in A. thaliana (5-7), but the enzymes responsible for the metabolism have yet to be purified and characterized.

Asano et al. have isolated various nitrile-degrading microorganisms, e.g., Rhodococcus rhodochrous (formerly Arthrobacter sp.) strains J-1 and I-9 (K22, AKU 629) (8)

† This work was supported in part by a Grant-in-Aid from the Japan Society for the Promotion of Science (JSPS) for Foreign Researchers (P00319 to S.-X. Xie) and a Grant-in-Aid for Scientific Research from the Ministry of Education, Science, and Culture of Japan.

$\doteqdot$ The nucleotide sequence reported in this paper has been submitted to the GenBank/EMBL/DDBJ Data Bank with accession number AB105912.

* To whom correspondence should be addressed. Phone: +81-76656-7500. Fax: +81-766-56-2498. E-mail: asano@pu-toyama.ac.jp.

$\S$ Postdoctoral fellow supported by the Japan Society for the Promotion of Science (JSPS). Present address: The High Throughput Screening Laboratory, University of Kansas, 1501 Wakarusa Dr., Lawrence, KS 66047. and Pseudomonas chlororaphis B23 (9). They first purified, characterized, and named nitrile hydratase (NHase, EC. 4.2.1.84) from $R$. rhodochrous $\mathrm{J}-1$ (10-12). They also found that $P$. chlororaphis B23 accumulates large quantities of amides from nitriles and is suitable for the industrial production of acrylamide from acrylonitrile $(9,12)$. Moreover, nicotinamide and 5-cyanovaleramide are also industrially produced by NHase $(13,14)$. Despite its important uses, the physiological function of NHase in nature remains unclear.

We have studied the metabolism of aldoximes from a physiological as well as an applicative perspective, and have isolated Bacillus sp. OxB-1 and Rhodococcus sp. YH3-3, which can convert aldoximes to the corresponding carboxylic acids, from soil samples. The reaction occurs via intermediary nitriles and involves a combination of enzymes including aldoxime dehydratase and nitrile-hydrolyzing enzymes such as nitrilase (Nit), ${ }^{1}$ and NHase, and/or amidase $(15-17)$ (Figure 1). We previously reported the purification and characterization of phenylacetaldoxime dehydratase $(\mathrm{OxdB})$ from Bacillus sp. OxB-1 and molecular cloning of the gene (oxd) (18). The enzyme was overexpressed in E. coli JM109 (19) and in a recombinant E. coli JM109/pOxD-90F strain employed in the enzymatic synthesis of various arylalkyland alkyl-nitriles from the corresponding aldoximes (20). The gene coding OxdB was linked with that for Nit in the genome of the Bacillus strain. We have also shown that aldoxime dehydratase activity coexists not only with Nit but also with

\footnotetext{
${ }^{1}$ Abbreviations: OxdRG, alkylaldoxime dehydratase from Rhodococcus globerulus A-4; OxdB, phenylacetaldoxime dehydratase from Bacillus sp. OxB-1; Nit, nitrilase; NHase, nitrile hydratase; PAOx, phenylacetaldoxime; PyOx, pyridine-3-aldoxime; PPOx, phenylpropionaldoxime; VOx, $n$-valeraldoxime; IPTG, isopropyl- $\beta$-D-thiogalactopyranoside; DMSO, dimethyl sulfoxide; ORF, open reading frame.
} 

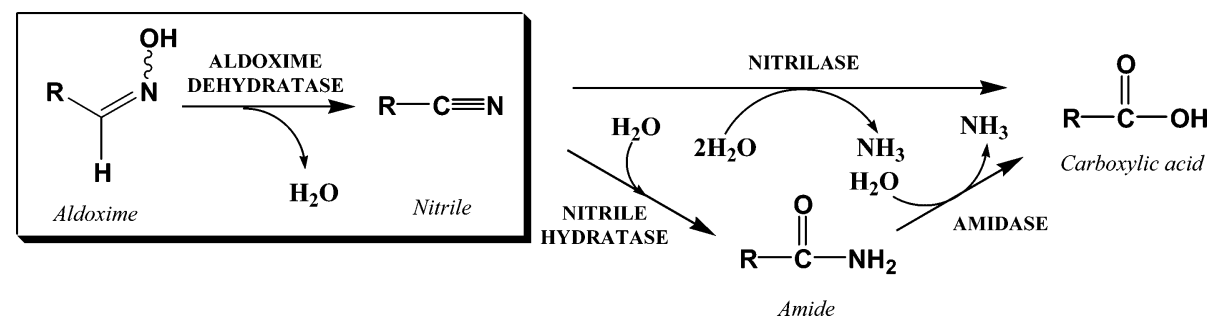

FIGURE 1: Microbial metabolism of aldoximes via the "aldoxime-nitrile" pathway. Bacillus sp. OxB-1 metabolizes Z-phenylacetaldoxime (Z-PAOx, $\mathrm{R}=\mathrm{PhCH}_{2}$ ) to form phenylacetonitrile using PAOx dehydratase $(\mathrm{OxdB})$, which is subsequently converted to phenylacetic acid by nitrilase. Rhodococcus globerulus A-4 metabolizes aldoximes such as E/Z-valeraldoxime (VOx, $\left.\mathrm{R}=\mathrm{CH}_{3}\left(\mathrm{CH}_{2}\right)_{3} 3^{-}\right)$and $Z$ - $\mathrm{PAOx}$ to the corresponding nitrile by the action of alkylaldoxime dehydratase, which is converted to the corresponding amide by nitrile hydratase, and the amide is then hydrolyzed to the corresponding acid by amidase.

NHase and amidase in various bacteria, yeasts, and fungi (20). Until now, however, aldoxime dehydratase has not been purified from a strain having NHase and amidase. It is of interest to show the possible enzymological and genetic relationships between aldoxime dehydratase and NHase/ amidase.

In this study, we examined the specificity of enzymes responsible for the metabolism of aldoximes and nitriles among newly isolated strains and stock cultures. Strain A-4, identified as $R$. globerulus exhibiting strong aldoxime dehydratase activity with a wide range of substrates together with NHase/amidase activity, was selected for the purification and characterization of an alkylaldoxime dehydratase. Its gene was cloned and overexpressed in E. coli, and its flanking region was sequenced. We found that the gene exists together with the NHase and amidase genes in the genome of $R$. globerulus A-4, providing the first evidence of a genetic relationship between aldoxime dehydratase and NHase/ amidase and the metabolism of alkylaldoximes.

\section{MATERIALS AND METHODS}

Materials. DEAE-Toyopearl 650 M, Butyl-Toyopearl 650 M, and HPLC columns G-3000SW and ODS-80TS were purchased from Tosoh Corp. (Tokyo, Japan). Gigapite was obtained from Seikagaku Kogyo (Tokyo, Japan). The FPLC columns Superdex 200 HR 10/30, MonoQ HR10/10, and Phenyl-Superose HR 5/5 were from Amersham Biosciences (Uppsala, Sweden). Aldoximes were synthesized from the corresponding aldehydes using the method demonstrated previously $(15,16,22)$. Other chemicals were from commercial sources and were used without further purification.

Analytical Methods. The molecular weight $\left(M_{\mathrm{r}}\right)$ of the enzyme was measured by HPLC on a TSK G3000SW column $(7.5 \times 600 \mathrm{~mm})$ or by SDS-PAGE as described previously $(18,23)$. SDS- and native-PAGE and proteinconcentration measurements were performed as described $(24,25)$. Heme staining was carried out using the method described by Goodhew C. F. et al (26). The absorption spectra were recorded on a HITACHI U-3210 spectrophotometer (Tokyo, Japan). The heme concentration was determined by the pyridine hemochromogen method (27) using the molecular extinction coefficient of the $\alpha$-peak at $557 \mathrm{~nm}$ of the hemochromogen of protoheme IX $\left(\epsilon=34.4 \mathrm{mM}^{-1}\right.$ $\mathrm{cm}^{-1}$ ) (28). To determine the $N$-terminal amino acid sequence, purified enzyme was blotted from the gel after SDSPAGE (12.5\% acrylamide) on a poly(vinylidene difluoride) membrane (PVDF, Bio-Rad, Hercules, CA) with the transblot semi-dry electrophoresis transfer cell (Nippon Eido,
Tokyo, Japan), aanalyzed with HP G1005A Protein Sequencing Systems (Hewlett-Packard Co., Palo Alto, CA).

Enzyme Assay. The standard assay mixture comprised, in $200 \mu \mathrm{L}, 0.1 \mathrm{M}$ potassium phosphate buffer (KPB, pH 7.0), $5 \mathrm{mM}$ of aldoxime, $10 \%$ (v/v) dimethyl sulfoxide (DMSO), and enzyme solution with $1 \mathrm{mM} \mathrm{Na}_{2} \mathrm{~S}$. After the enzyme reaction was run at $30^{\circ} \mathrm{C}$ for $10-30 \mathrm{~min}$, during which the enzyme reaction proceeded linearly, the reaction was stopped by adding an equal volume of $0.5 \mathrm{M} \mathrm{H}_{3} \mathrm{PO}_{4}$ followed by vortexing. The mixture was analyzed by GLC or HPLC as described previously $(18,20,21)$. One unit of enzyme activity is defined as the amount of enzyme that catalyzes the dehydration of aldoxime into nitrile at a rate of $1 \mu \mathrm{mol}$ per min under the assay conditions.

Screening for Aldoxime-Degrading Microorganisms. Microorganisms stocked in our laboratory and isolates from soil such as aldoxime or nitrile degraders were used for screening. TGY medium, which comprised $0.5 \%$ Bacto Tryptone (Difco, Detroit, MI), 0.5\% yeast extract (Difco), 0.1\% glucose, and $0.1 \% \mathrm{~K}_{2} \mathrm{HPO}_{4}, \mathrm{pH} 7.0$, was used to culture microorganisms. Each microorganism was inoculated in a test tube $(16.5 \times 165 \mathrm{~mm})$ containing $5 \mathrm{~mL}$ of TGY medium with $0.05 \%$ of various aldoximes as inducers, and then incubated at $30{ }^{\circ} \mathrm{C}$ for $12-36 \mathrm{~h}$ with reciprocal shaking (200 strokes/min). Five milliliters of seed culture was transferred to a $2 \mathrm{~L}$ Sakaguchi flask containing $500 \mathrm{~mL}$ of the same medium, followed by incubation at $30^{\circ} \mathrm{C}$ for $12-24 \mathrm{~h}$ with reciprocal shaking ( 96 strokes $/ \mathrm{min}$ ). The cells were harvested by centrifugation at $15200 \mathrm{~g}$ for $20 \mathrm{~min}$ at $4{ }^{\circ} \mathrm{C}$, and washed with $0.85 \%$ saline and $50 \mathrm{mM} \mathrm{KPB} \mathrm{(pH} \mathrm{7.0).} \mathrm{Each} \mathrm{reaction}$ mixture comprised 5\% (w/v) of wet cells, $0.1 \mathrm{M} \mathrm{KPB} \mathrm{(pH}$ 7.0), and $50-100 \mathrm{mM}$ of substrate such as E-pyridine-3aldoxime (E-PyOx), Z-PAOx, Z-3-phenylpropionaldoxime (Z-3-PPOx), E/Z-2-phenylpropionaldoxime (E/Z-2-PPOx), or $E / Z$-isobutyraldoxime in a total volume of $400 \mu \mathrm{L}$. The reaction was run for $2 \mathrm{~h}$ at $30{ }^{\circ} \mathrm{C}$, and then two volumes of ethyl acetate or one volume of $0.5 \mathrm{M} \mathrm{H}_{3} \mathrm{PO}_{4}$ was added to stop it. The product formation was analyzed by GC or HPLC.

Identification of Strain A-4. The taxonomic characteristics of the strain were examined by the method described in Bergey's Manual of Systematic Bacteriology (29). Fatty acid composition of the cells was analyzed by GLC and evaluated by Sherlock Microbial Identification System (MIDI, Inc., Newark, DE) (30). Sequencing of the PCR-amplified 16S rDNA-500 was done by ABI PRISM377 DNA sequencer (Applied Biosystems, Foster City, CA) and compared with a database of MicroSeq Bacterial 500 Library V.0023 (Applied Biosystems). 
Purification of an Aldoxime Dehydratase from R. globerulus A-4. All purification procedures were performed at temperatures lower than $5^{\circ} \mathrm{C}$. Twenty millimolar $\mathrm{KPB}(\mathrm{pH}$ 7.0) containing $0.2 \mathrm{mM}$ dithiothreitol and $5 \mathrm{mM}$ 2-mercaptoethanol was used throughout the purification. Centrifugation was done at $19700 \mathrm{~g}$ for $20 \mathrm{~min}$ unless otherwise specified. Washed cells (294 $\mathrm{g}$ of wet weight) of $R$. globerulus A-4 obtained from 100 L of TGY culture containing $0.05 \%$ E-PyOx were suspended in $2.5 \mathrm{~L}$ of the buffer, and then disrupted for $3 \times 20 \mathrm{~min}$ at $4{ }^{\circ} \mathrm{C}$ by an Insonator model 201M (9 kHz, Kubota-Shoji, Tokyo, Japan). After centrifugation, the resulting supernatant was fractionated with solid $\left(\mathrm{NH}_{4}\right)_{2} \mathrm{SO}_{4}$. The precipitate obtained at 30$60 \%$ saturation was collected, dissolved, and dialyzed against four changes of $20 \mathrm{~L}$ of the buffer. The dialysate was put on a DEAE-Toyopearl column $(6.3 \times 40 \mathrm{~cm})$ and eluted with a linear gradient of $0-1 \mathrm{M} \mathrm{NaCl}$ in $8 \mathrm{~L}$ of buffer and the active fractions were combined. After the $\left(\mathrm{NH}_{4}\right)_{2} \mathrm{SO}_{4}$ concentration had been adjusted to $20 \%$ saturation, the enzyme solution was loaded onto a Butyl-Toyopearl column $(5.7 \times 20 \mathrm{~cm})$ and eluted by lowering the ionic strength of $\left(\mathrm{NH}_{4}\right)_{2} \mathrm{SO}_{4}$ linearly from $20 \%$ saturation to $0 \%$ in $5 \mathrm{~L}$ of buffer. The active fractions were collected and dialyzed against four changes of $10 \mathrm{~L}$ of buffer. The dialyzate was collected and concentrated with a Centriprep YM-10 membrane (Millipore, MA), and then added to a Gigapite column $(5.6 \times 25 \mathrm{~cm})$. The enzyme was eluted with a linear gradient of $0-5 \mathrm{M} \mathrm{KPB}(\mathrm{pH} 7.0)$ in $4 \mathrm{~L}$ of the buffer. The active fractions were dialyzed, concentrated, and put on a second DEAE-Toyopearl column $(2.8 \times 45 \mathrm{~cm})$. The enzyme was eluted with a linear gradient of $0.1-0.5 \mathrm{M} \mathrm{NaCl}$ in $1.5 \mathrm{~L}$ of buffer. The enzyme solution was again purified with a second Butyl-Toyopearl chromatography column $(2.8 \times 28 \mathrm{~cm})$ using a linear gradient of $\left(\mathrm{NH}_{4}\right)_{2} \mathrm{SO}_{4}$ (15 to $0 \%$ saturation in $1 \mathrm{~L}$ of buffer). The dialyzed active fraction was purified with a Superdex 200 HR 10/30 column using buffer containing $0.15 \mathrm{M} \mathrm{NaCl}$. The active fractions were dialyzed, concentrated, then loaded onto a MonoQ HR10/10 column and eluted with a linear gradient of $0-1 \mathrm{M} \mathrm{NaCl}$ in buffer. After adding $\mathrm{NaCl}$ to a concentration of $4 \mathrm{M}$, the active enzyme solution was applied to a PhenylSuperose HR 5/5 column and eluted with a linear gradient of $\mathrm{NaCl}$ (4 to $0 \mathrm{M}$ ). The active fractions were collected, dialyzed, and concentrated for enzyme characterization.

Bacterial Strains, Plasmids, and Culture Conditions. $R$. globerulus A-4 was used as a source of chromosomal DNA throughout this study. E. coli JM109 (recA1, endA1, gyrA96, thi, hsdR 17, supE44, relA1, $\Delta($ lac-proAB $) / \mathrm{F}^{\prime}$ [traD36, $\operatorname{proAB}^{+}, \operatorname{lacI}^{\mathrm{q}}$, lacZ $\left.\left.\Delta \mathrm{M} 15\right]\right)$ was used as a host strain for gene cloning and in DNA manipulations. Plasmids pBluescriptII SK- and pUC19 were employed as a cloning vector and for sequencing analysis. Plasmid DNA was isolated with an automatic plasmid isolation system PI-100 (Kurabo, Osaka, Japan) or by using a QIAGEN plasmid purification kit (Valencia, CA). Recombinant $E$. coli cells were cultivated at 25,30 , or $37^{\circ} \mathrm{C}$ in Luria-Bertani (LB) medium ( $1 \%$ Bacto Tryptone, $0.5 \%$ Bacto yeast extract, and $1 \% \mathrm{NaCl}, \mathrm{pH} 7.0)$ containing $100 \mu \mathrm{g} / \mathrm{mL}$ of ampicillin. Terrific medium $(1.2 \%$ Bacto Tryptone, $2.4 \%$ Bacto yeast extract, $0.4 \%$ glycerol, $17 \mathrm{mM} \mathrm{KH}_{2} \mathrm{PO}_{4}$, and $72 \mathrm{mM} \mathrm{K} \mathrm{HPO}_{4}, \mathrm{pH} 7.3$ ) was used for overexpressing the enzyme. To induce the lac-promoter,
$1 \mathrm{mM}$ of isopropyl- $\beta$-D-thiogalactopyranoside (IPTG) was added to the medium.

Cloning of oxd and Its Flanking Sequences. The sense primer ATGGARWSSGCNATCGGNGAR and antisense primer CTG GTGSARSGTRTCRTCNGC were synthesized on the basis of the sequences of MESAIGE and ADDTLHQ, respectively, which were part of the $N$-terminal amino acid sequence of the purified aldoxime dehydratase. Degenerate positions are indicated by $\mathrm{R}$ for $\mathrm{A}$ or $\mathrm{G}, \mathrm{W}$ for $\mathrm{A}$ or $\mathrm{T}, \mathrm{S}$ for $\mathrm{C}$ or $\mathrm{G}$, and $\mathrm{N}$ for all bases. The genomic DNA of $R$. globerulus A-4 was isolated as described previously (31) and used as a template for PCR amplification with a PTC-200 thermal cycler (MJ Research Inc., Watertown, MA). Reaction mixtures contained $2.5 \mathrm{ng}$ of chromosomal DNA, $100 \mathrm{pmol}$ of each primer, and 1 unit of Thermus aquaticus DNA polymerase (EX Taq, Takara, Japan) in a volume of $50 \mu \mathrm{L}$. Thirty-five thermal cycles were employed, each consisting of $95^{\circ} \mathrm{C}$ for $0.5 \mathrm{~min}, 55^{\circ} \mathrm{C}$ for $1.5 \mathrm{~min}$, and $72{ }^{\circ} \mathrm{C}$ for 2.5 min. The gel-purified PCR product $(\sim 120$-bp) was cloned into pT7Blue vector (Novagen, Darmstadt, Germany) to construct a plasmid pOxdRGNS, and then introduced into E. coli JM109. The PCR product was purified from the plasmid and used as a radiolabeled probe for Southern hybridization to clone the full-length aldoxime dehydratase gene as described previously (18). The $4.5 \sim 6.0 \mathrm{~kb}$ fragment of the genomic DNA digested with BamHI was purified and inserted into the same site of pBluescript II KS - to construct a genomic library of $R$. globerulus A-4. While colony hybridization was performed, one positive clone, harboring pOxdRGB97, which contains about a 4.7-kb BamHI fragment, was selected for further analysis. The positive fragment was inserted into the BamHI site of pUC19 for sequencing with the Kilo-sequence Deletion kit (Takara). Sequence analysis of the deletion templates was performed by the dideoxy chain termination procedure (32) with an automatic DNA sequencer 4000L (LiCor, Lincoln, NB) or a model 310 (Applied Biosystems). The positive 3.9-kb FbaI and 6.3-kb PstI fragments were also obtained in the manner described above. Another 3.7-kb HindIII-SphI fragment was cloned by the DNA-probing method with a 0.7-kb HindIII-PstI fragment as a probe that was obtained by HindIII digestion of the 6.3-kb PstI fragment. The entire 11.6-kb DNA containing oxd and its flanking region was sequenced. A homology search was performed with the sequence similarity searching programs FASTA (33) and BLAST (34) and the ClustalW method was used to align the sequences (35). The GENETYX software system (Software Development Co., Tokyo, Japan) was used for computer analysis of nucleotide sequences and deduced amino acid sequences.

Overexpression of oxd Gene Product of R. globerulus A-4 in E. coli. Restriction mapping of pOxdRGB97, subcloning into the vector pBluescriptII SK-, and subsequent Southern blot hybridization analysis yielded a $1.5-\mathrm{kb}$ HincII fragment containing oxd of $R$. globerulus A-4, which was subcloned into the vector pUC19 to make pOxdRG HII. The 5'-flanking region of the ATG start codon of the oxd gene was modified by PCR with pOxdRGHII as a template. PCR was carried out in a reaction mixture $(50 \mu \mathrm{L})$ containing $25 \mathrm{ng}$ of template DNA, 100 pmol of each primer: for the $N$-terminal, 5'-TCGACCAAGCTTTAAGGAGGAATAGCTCATGGAATCTGCAATCGGCGAACACC-3' (the translation start codon is underlined; ribosome-binding site is in bold; 
Table 1: Purification of the Aldoxime Dehydratase from Rhodococcus globerulus A-4

\begin{tabular}{|c|c|c|c|c|c|}
\hline step & total protein $(\mathrm{mg})$ & total activity (units) & 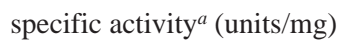 & yield $(\%)$ & specific activity ratio ${ }^{b}$ \\
\hline cell-free extract & 16900 & 14.3 & 0.000845 & 100 & 0.956 \\
\hline ammonium sulfate & 5970 & 7.96 & 0.00133 & 55.7 & 0.858 \\
\hline DEAE-Toyopearl (I) & 2560 & 4.43 & 0.00173 & 31.0 & 0.924 \\
\hline Butyl-Toyopearl (I) & 567 & 3.25 & 0.00574 & 22.7 & 1.81 \\
\hline Gigapite & 347 & 2.86 & 0.00826 & 20.0 & 3.49 \\
\hline DEAE-Toyopearl (II) & 236 & 2.54 & 0.0107 & 17.8 & 6.73 \\
\hline Butyl-Toyopearl (II) & 176 & 2.37 & 0.0134 & 16.6 & 8.24 \\
\hline Superdex 200 HR 10/30 & 40.4 & 1.92 & 0.0475 & 13.4 & 16.3 \\
\hline MonoQ HR 10/10 & 26.2 & 1.67 & 0.0636 & 11.7 & 17.7 \\
\hline Phenyl-Superose HR 5/5 & 8.77 & 0.772 & 0.0879 & 5.41 & 8.93 \\
\hline
\end{tabular}

${ }^{a}$ The reaction was carried out with $5 \mathrm{mM} \mathrm{Z-PAOx}$ as the substrate in the presence of $1 \mathrm{mM} \mathrm{Na}_{2} \mathrm{~S} .{ }^{b}$ Ratio of specific activities determined with and without $\mathrm{Na}_{2} \mathrm{~S}$.

restriction site is in italics), and for $C$-terminal, 5'-AACATATCTAGAGTTGCCTCCGAGGG-3' (restriction site is in italics), and $0.5 \mathrm{U}$ of $P$ wo polymerase (Roche, Mannheim, Germany). Thirty thermal cycles were employed, each consisting of $94{ }^{\circ} \mathrm{C}$ for $0.5 \mathrm{~min}, 55^{\circ} \mathrm{C}$ for $0.5 \mathrm{~min}$, and 72 ${ }^{\circ} \mathrm{C}$ for 2 min. The PCR product was digested with HindIII and $X b a \mathrm{I}$, and the gel-purified fragment was inserted into the same site of pUC19. The plasmid thus obtained was used to transform E. coli JM109 afforded the overexpression plasmid pOxdRGP9. Base sequencing confirmed the nucleotide sequence of the complete amplified gene and showed that no error had been incorporated during PCR.

Purification of the Recombinant Enzyme. E. coli JM109/ pOxdRGP9 was cultured in $3 \mathrm{~mL}$ of LB medium containing $100 \mu \mathrm{g} / \mathrm{mL}$ of ampicillin at $37^{\circ} \mathrm{C}$ for $12 \mathrm{~h}$. The seed culture was transferred to a $2-\mathrm{L}$ Erlenmeyer flask containing $1.5 \mathrm{~L}$ of Terrific medium with $100 \mu \mathrm{g} / \mathrm{mL}$ of ampicillin and $1 \mathrm{mM}$ IPTG, and was incubated at $25^{\circ} \mathrm{C}$ for $158 \mathrm{~h}$ with a 200 -rpm shaking rate. The cells were harvested by centrifugation at $15200 \mathrm{~g}$ for $20 \mathrm{~min}$, and washed with $0.85 \% \mathrm{NaCl}$ and 50 $\mathrm{mM}$ KPB, pH 7.0. The cells (20 g of wet weight) were sonicated and fractionated with $\left(\mathrm{NH}_{4}\right)_{2} \mathrm{SO}_{4}(20-60 \%$ saturation). The dialyzed enzyme was subsequently purified with DEAE-Toyopearl $(4.3 \times 25 \mathrm{~cm})$, Butyl-Toyopearl $(2.8 \times$ $30 \mathrm{~cm}$ ), MonoQ HR10/10, Phenyl-Superose HR 5/5, Superdex 200 HR 10/30, Gigapite, and MonoQ HR5/5 columns. The active fractions were collected, dialyzed, and concentrated for further analysis.

\section{RESULTS}

Screening for Aldoxime-Degrading Microorganisms. Various bacterial strains in TPU stock cultures and isolates from soil were screened for aldoxime- and nitrile-degrading activities. Among them, the unidentified strain A-4, Rhodococcus sp. YH3-3 (16), Corynebacterium sp. C5 TPU 6015 (21), and Rhodococcus sp. N-774 (21) converted not only Z-PAOx, but also substituted alkyaldoximes, such as E/Z2-PPOx and E/Z-isobutyraldoxime, and arylaldoxime, $E$ $\mathrm{PyOx}$, to the corresponding nitriles. The nitriles were further degraded to the corresponding carboxylic acids through amides, suggesting that the strains metabolize the aldoximes via the actions of aldoxime dehydratase, NHase, and amidase. The active strains were different from Bacillus sp. OxB-1 which did not act on the aryl- and substituted aldoximes and degraded nitriles by the action of Nit. Strain A-4 was selected for further study because it showed the highest levels of activity for aldoxime- and nitrile-degradation. Strain A-4 was identified as R. globerulus based on the following taxonomical characteristics according to Bergey's Manual of Systematic Bacteriology (29). The cells were singular, non-spore forming, and gram-positive irregular rods. A typical rodcoccus growth cycle was observed. The colonies were orange on a nutrient agar. Catalase was present and oxidase was not. No acid or gas was produced from typical sugars, such as glucose, ribose, xylose, mannitol, maltose, lactose, and glycogen. Alkaline phosphatase and $\alpha$-glucosidase were detected. $\beta$-Glucuronidase, $\beta$-galactosidase, and $N$-acetyl- $\beta$ glucosaminidase were absent. Major fatty acids present were tetradecanoic $(5.3 \%)$, pentadecanoic $(5.6 \%)$, hexadecanoic (19.1\%), 8-cis-heptadecenoic (5.7\%), 10-methyl-octadecanoic (9.5\%), 9-cis-octadecenoic (17.6\%), and nonadecenoic $(6.7 \%)$ acids. The partial sequencing of the $16 \mathrm{~S}$ rDNA showed $99.8 \%$ similarity with that of $R$. globerulus.

Purification of the Wild-Type Aldoxime Dehydratase. The wild-type enzyme was purified to homogeneity through a 10-step purification procedure as shown in Table 1 . The enzyme was purified 104-fold with a yield of 5.4\% from the cell-free extract of $R$. globerulus A-4, by measuring the enzyme activity with Z-PAOx as the substrate. The purified enzyme (OxdRG) gave a single band on SDS-PAGE (Figure 2) and a single peak by HPLC on a TSK G-3000 SW column. The $M_{\mathrm{r}}$ of the subunit was estimated to be 42000 by comparing the mobility on SDS-PAGE to that of standard proteins and the $M_{\mathrm{r}}$ of the native enzyme was 76200 according to gel filtration chromatography. These results suggest that the enzyme has a dimeric structure. The $N$-terminal 40 amino acid sequence of the native OxdRG protein was determined to be MESAIGEHLQCPRTLTRRVPDTYTPPFPMWVGRADDTLHQ. It did not show significant similarity to any known proteins including OxdB.

Optical Spectrum and Prosthetic Group. The absorption maxima of the purified OxdRG enzyme were at 273, 359, 421, and $549 \mathrm{~nm}$, indicating that the enzyme contains heme. Furthermore, the enzyme was positively stained by heme staining on native-PAGE gel (26). The pyridine hemochrome was prepared by mixing the enzyme with alkaline-pyridine for examining the properties of the heme in the enzyme. The absorption peaks of the hemochromogen occurred at 417 (Soret), 524 ( $\alpha$-band), and 556 ( $\beta$-band) (Figure 3A, dotted line), which are characteristic of the reduced pyridine hemochrome of protoheme IX (28). The addition of a few crystals of $\mathrm{Na}_{2} \mathrm{~S}_{2} \mathrm{O}_{4}$ caused the increase of each band of the hemochromogen without any changes in their absorbance wavelength (Figure 3A, solid line). These results indicate 
A B

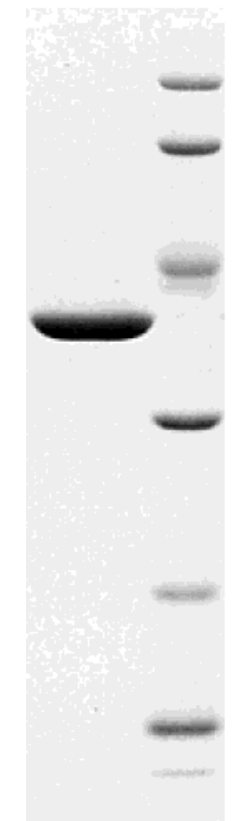

(A)

\author{
97,400 \\ 66,267 \\ 45,000
}

30.000

20,100

14,400

FIGURE 2: SDS-PAGE of the aldoxime dehydratase purified from $R$. globerulus A-4. Forty micrograms of protein were loaded onto the lane. Lane A, purified enzyme. Lane B, marker proteins: phosphorylase $\left(M_{\mathrm{r}}=97400\right)$, bovine serum albumin (66 267), ovalbumin (45000), carbonic anhydrase (30 000), soybean trypsin inhibitor (20 100), and $\alpha$-lactalbumin (14 400).

that the heme iron was present in a reduced form. The heme prosthetic group could be extracted from the enzyme by $\mathrm{HCl} /$ acetone-treatment (28) and the extract then concentrated in vacuo. The pyridine hemochrome of the extracted heme exhibited the oxidized-type spectrum of protoheme IX (Figure 3B, dotted line) and the same spectrum as that in Figure $3 \mathrm{~A}$ was obtained on adding $\mathrm{Na}_{2} \mathrm{~S}_{2} \mathrm{O}_{4}$ (Figure $3 \mathrm{~B}$, solid line). The heme content of the enzyme was calculated to be $0.37 \mathrm{~mol}$ heme $/ \mathrm{mol}$ enzyme determined from the spectrum of its pyridine hemochromogen. The value is quite close to that of $\mathrm{OxdB}, 0.33$ (18). The absorption spectra of the hemochromogen were measured with several types of compounds. In the presence of $\mathrm{CO}$, the peaks of Soret, the $\alpha$-band, and the $\beta$-band decreased and a new shoulder at $430 \mathrm{~nm}$ appeared. On the other hand, no significant change in the spectrum was observed with $\mathrm{KCN}$ and various aldoximes and nitriles.

Effects of Reducing Reagents on the Enzyme Activity. The purified enzyme activity was remarkably enhanced by the addition of reducing reagents to the assay. The activity for Z-PAOx dehydration was enhanced 8.35-, 7.51-, 8.13-, 5.84-, 2.13-, 4.06-, 2.39-, and 3.93-fold in the presence of $1 \mathrm{mM}$ of $\mathrm{Na}_{2} \mathrm{~S}, \mathrm{Na}_{2} \mathrm{SO}_{3}, \mathrm{Na}_{2} \mathrm{~S}_{2} \mathrm{O}_{4}, \mathrm{Na}_{2} \mathrm{~S}_{2} \mathrm{O}_{5}, 2$-mercaptoethanol, thioglycerol, L-cysteine, and cysteamine, respectively. The activity was not increased by addition of $\mathrm{NaHSO}_{3}, \mathrm{Na}_{2} \mathrm{SO}_{4}$, $\mathrm{NaHSO}_{4}$, or $\mathrm{Na}_{2} \mathrm{~S}_{2} \mathrm{O}_{7}$. Due to ease of handling, $1 \mathrm{mM}$ of $\mathrm{Na}_{2} \mathrm{~S}$ was added to the assay mixtures. The apparent $K_{\mathrm{m}}$ value for $\mathrm{Na}_{2} \mathrm{~S}$ was estimated to be $40.8 \mu \mathrm{M}$. No further enhancement of the activity was seen when reducing reagents coexisted with $\mathrm{Na}_{2} \mathrm{~S}$ in the assay mixture. The activity was not enhanced when the assay was carried out anaerobically, conditions under which OxdB activity was increased over 5-fold (18).

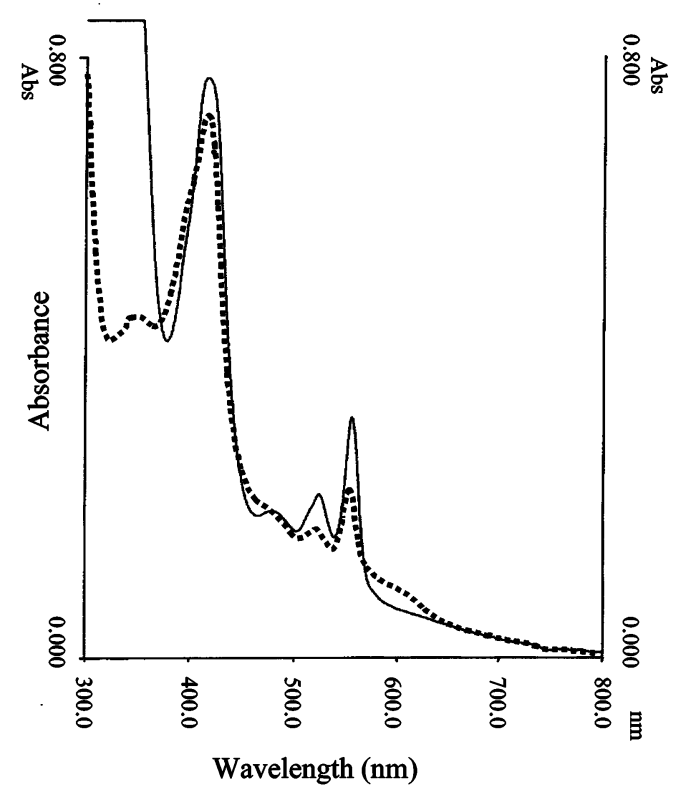

(B)

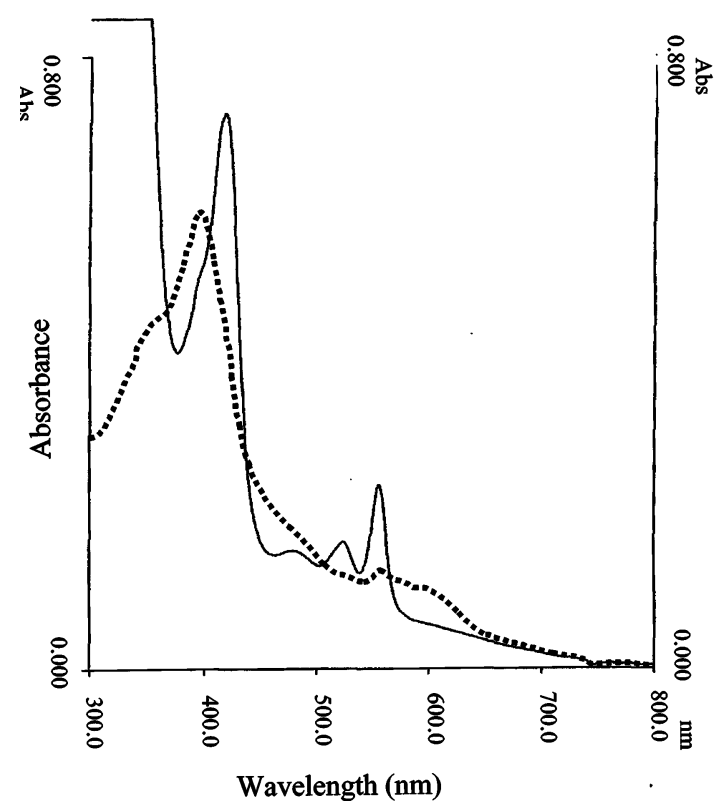

FIGURE 3: Absorption spectra of the pyridine hemochromogen of (A) native- and (B) extracted-heme of the aldoxime dehydratase from $R$. globerulus A-4. (A) $150 \mu \mathrm{L}$ of the enzyme solution $(4.0$ $\mathrm{mg} / \mathrm{mL}$ ) in $20 \mathrm{mM}$ potassium phosphate buffer ( $\mathrm{pH}$ 7.0) was mixed with $450 \mu \mathrm{L}$ of pyridine containing $0.1 \mathrm{~N} \mathrm{KOH}$. (B) The heme prosthetic group was extracted from $150 \mu \mathrm{L}$ of the enzyme (4.0 $\mathrm{mg} / \mathrm{mL}$ ) by $\mathrm{HCl} /$ acetone-treatment then concentrated in vacuo, and the extracted heme was mixed with $600 \mu \mathrm{L}$ of $50 \%$ pyridine containing $0.1 \mathrm{~N} \mathrm{KOH}$. Solid and dotted lines represent results obtained in the presence and absence of $\mathrm{Na}_{2} \mathrm{~S}_{2} \mathrm{O}_{4}$, respectively.

The activity was increased 1.7-, 1.2-, and 1.1-fold by 1 $\mathrm{mM}$ of the flavins, FMN, FAD, and riboflavin, respectively. Furthermore, the activity was increased 2.4-, 4.5-, and 4.2fold, respectively, when $\mathrm{Na}_{2} \mathrm{~S}$ was omitted from the assay. The following coenzymes did not affect the reaction: pantothenate, phosphoenolpyruvate, NaF, pyridoxal, pyridoxal-5'-phosphate (PLP), ascorbate, dehydroascorbate, glu- 


\begin{tabular}{|c|c|c|c|c|}
\hline aldoxime & $K_{\mathrm{m}}(\mathrm{mM})$ & $V_{\max }$ (units/mg) & $V_{\max } / K_{\mathrm{m}}($ units $/ \mathrm{mg} / \mathrm{mM})$ & relative act $(\%)^{a}$ \\
\hline $\begin{array}{l}\text { Alkylaldoxime } \\
\text { E/Z-cyclohexanecarboxaldehyde oxime } \\
\text { E/Z-propionaldoxime } \\
\text { E/Z-n-butyraldoxime } \\
\text { E/Z-isobutyraldoxime } \\
\text { E/Z-VOx } \\
\text { E/Z-isovaleraldoxime } \\
\text { E/Z-n-capronaldoxime } \\
\text { E/Z-isocapronaldoxime }\end{array}$ & $\begin{array}{l}1.13 \\
5.13 \\
1.73 \\
5.54 \\
1.13 \\
3.97 \\
2.94 \\
6.76\end{array}$ & $\begin{array}{l}0.386 \\
0.430 \\
0.689 \\
0.041 \\
1.64 \\
0.239 \\
1.66 \\
1.32\end{array}$ & $\begin{array}{l}0.342 \\
0.084 \\
0.398 \\
0.007 \\
1.45 \\
0.060 \\
0.565 \\
0.195\end{array}$ & $\begin{array}{l}100 \\
7.76 \\
48.9 \\
26.5 \\
39.3 \\
58.6 \\
64.2 \\
88.3\end{array}$ \\
\hline $\begin{array}{l}\text { Arylalkylaldoxime } \\
\text { Z-PAOx } \\
\text { E/Z-2-PPOx } \\
\text { Z-3-PPOx } \\
\text { E/Z-4-phenylbutyraldoxime } \\
\text { E/Z-indoleacetaldoxime } \\
\text { E/Z-mandelaldoxime }\end{array}$ & $\begin{array}{l}1.40 \\
11.9 \\
2.31 \\
\mathrm{ND}^{b} \\
3.91 \\
3.23\end{array}$ & $\begin{array}{l}0.140 \\
0.810 \\
0.392 \\
\mathrm{ND}^{b} \\
0.281 \\
0.572\end{array}$ & $\begin{array}{l}0.100 \\
0.068 \\
0.170 \\
\mathrm{ND}^{b} \\
0.072 \\
0.177\end{array}$ & $\begin{array}{c}26.6 \\
5.23 \\
67.3 \\
5.23 \\
7.29 \\
3.09\end{array}$ \\
\hline $\begin{array}{l}\text { Arylaldoxime } \\
E \text {-PyOx }\end{array}$ & 20.0 & 0.065 & 0.003 & 0.781 \\
\hline
\end{tabular}

${ }^{a}$ Substrate concentration was $5 \mathrm{mM}$. Low levels of activity $(0.04-0.8 \%)$ were seen for E/Z-cinnamaldoxime, Z-p-chlorophenylacetaldoxime, $Z$-naphthoacetaldoxime, $E$-thiophene-2-carboxaldoxime, $E$-thiophene-2 acetaldoxime, $E$-benzaldoxime, $E$-p-chlorobenzaldoxime, $E$-furfurylaldoxime, and $E$-p-tolualdoxime. ${ }^{b} \mathrm{ND}$ : not determined.

tathione, glutathione disulfide, $\mathrm{NAD}(\mathrm{P})(\mathrm{H})$, $\mathrm{CoA}-\mathrm{SH}, \mathrm{AMP}$, ADP, ATP, GMP, GDP, GTP, IMP, IDP, and ITP.

Effects of $\mathrm{pH}$ and Temperature on the Enzyme Activity and Stability. The effects of $\mathrm{pH}$ and temperature on the enzyme activity and stability were measured in $0.1 \mathrm{M}$ buffers at various pHs: $\mathrm{AcOH} / \mathrm{AcONa}, \mathrm{pH} 3.5-6.0 ; \mathrm{KPB}, \mathrm{pH} 6.0-$ 8.5; Tris/HCl, $\mathrm{pH}$ 7.5-9.0; ethanolamine/ $\mathrm{HCl}, \mathrm{pH}$ 8.5-11.0; $\mathrm{NH}_{4} \mathrm{Cl} / \mathrm{NH}_{4} \mathrm{OH}, \mathrm{pH} 8.0-10.5$; and glycine $/ \mathrm{NaCl} / \mathrm{NaOH}, \mathrm{pH}$ $8.5-13.0$, or at various temperatures between 20 and $80^{\circ} \mathrm{C}$ in $0.1 \mathrm{M} \mathrm{KPB}, \mathrm{pH}$ 8.0. The enzyme exhibited the highest activity in $\mathrm{KPB}, \mathrm{pH} 8.0$, at $30^{\circ} \mathrm{C}$. About $65 \%$ of the activity remained after incubation at $40^{\circ} \mathrm{C}$ for $30 \mathrm{~min}$ in $0.1 \mathrm{M} \mathrm{KPB}$, $\mathrm{pH}$ 8.0. The activity was maintained at approximately $75 \sim 99 \%$ between $\mathrm{pH} 6.0$ and 9.5 after incubation at $30{ }^{\circ} \mathrm{C}$ for $30 \mathrm{~min}$.

Substrate Specificity and Kinetic Properties. The substrate specificity of the purified enzyme was examined with various "synthetic" aldoximes as shown in Table 2. The enzyme was active toward various arylalkyl- and alkyl-aldoximes, and to a lesser extent to arylaldoximes, converting them to the corresponding nitriles. Since all the tested arylaldoximes were of the $E$-form, we synthesized Z-PyOx as described previously (22) and tested it as a substrate. However, we could not detect any activity with this aldoxime, suggesting that the enzyme does not utilize arylaldoximes to any great extent regardless of the geometry about the $\mathrm{CN}$ double bond. The enzyme also acted on E/Z-2-PPOx, E/Z-mandelaldoxime, and $E / Z$-isobutyraldoxime, all of which have a substituent group at the aldoxime $\alpha$-site although relative activity levels were low. The following compounds were inert as substrates: E/Z$p$-hydroxyphenylacetaldoxime, E/Z-diphenylacetaldoxime, $E$-1-naphthoaldoxime, $E$-anisaldoxime, $E$-quinoline-2-carboxaldehyde oxime, $E$-terephthalaldehyde oxime, $E$-isophthalaldehyde oxime, E-pyrazinecarboxaldoxime, $Z$-crotonaldoxime, $E / Z$-methacrylaldoxime, $E / Z$ - $O$-benzyl-PAOx, $E$-PAOx-hydrazone, $E / Z$ - $O$-acetyl-PAOx, E/Z-phenylacetone oxime, and $E / Z$-acetophenone oxime. Values for $V_{\max }$ and $K_{\mathrm{m}}$ were determined using Lineweaver-Burk double reciprocal plots (Table 2). The $K_{\mathrm{m}}$ values for arylalkyl- and alkylaldoximes were nearly the same and much lower than the value for arylaldoxime, whereas the $V_{\max }$ values for the former except for $E / Z$-isobutyraldoxime were greater than that of the latter. Arylaldoxime was not a good substrate for the enzyme. On the basis of the results, we tentatively name the enzyme "alkylaldoxime dehydratase (EC 4.3.1.-)".

Effects of Various Compounds on the Enzyme Activity. The enzyme activity was assayed under standard conditions in the presence of various metal ions and compounds using E/ZVOx and Z-PAOx as alkyl- and arylalkyl-type substrate, respectively, and compared with that of a control (Table 3 ). E/Z-VOx and Z-PAOx dehydration activity was enhanced by $1 \mathrm{mM}$ of $\mathrm{Fe}^{2+}$ 2.92- and 5.34-fold, respectively, while 1 $\mathrm{mM} \mathrm{Fe}{ }^{3+}$ also increased the activity, 8.35- and 15.8-fold, respectively. In the absence of $\mathrm{Na}_{2} \mathrm{~S}$, the enhancement by $\mathrm{Fe}^{3+}$ was 5.29- and 6.32-fold, respectively. The metal ions, $\mathrm{Cu}^{+}, \mathrm{Cu}^{2+}, \mathrm{Co}^{2+}, \mathrm{Zn}^{2+}$, and $\mathrm{Cd}^{2+}$, strongly inhibited the reaction for both substrates at $1 \mathrm{mM}$; however, they enhanced the activity when their concentration was low $(0.1 \mathrm{mM})$. The enzyme activity was also inhibited by $1 \mathrm{mM}$ concentrations of heavy metal ions and sulfhydryl reagents. Phenylhydrazine inhibited Z-PAOx dehydration, but not E/Z-VOx dehydration, as did Tiron (4,5-dihydroxy-1,3-benzene-disulfonic acid) whereas typical carbonyl reagents, such as hydrazine, $\mathrm{KCN}$, $\mathrm{NaN}_{3}$, and $\mathrm{NH}_{2} \mathrm{OH}$, did not reduce activity for either substrate. The enzyme activity was slightly inhibited by electron donors and carriers such as trimethylhydroquinone, $p$-phenylenediamine, dimethylphenylenediamine, tetramethylphenylenediamine, guaiacol, pyrogallol, miconazole, nitroblue tetrazolium, and phenazine methosulfate, while the electron acceptors, such as vitamin $\mathrm{K}_{3}$ and duroquinone, were found to enhance the activity.

Cloning and Sequence Analysis of the oxd. To clone the gene encoding the enzyme, PCR was performed using primers designed on the basis of its $N$-terminal protein sequence with the total genomic DNA of $R$. globerulus A-4 as the template. A single 120-bp fragment was consistently amplified and the putative protein sequence derived from this fragment was identical to the $N$-terminal sequence of the purified enzyme. Using this 120-bp fragment as a probe, genomic Southern hybridization was performed to obtain the 
Table 3: Effect of Various Compounds on the Enzyme Activity Measured with E/Z-VOx and Z-PAOx as Substrates

\begin{tabular}{lllc}
\hline & & \multicolumn{2}{c}{ relative activity $(\%)^{a}$} \\
\cline { 3 - 4 } \multicolumn{1}{c}{ compound } & conc $(\mathrm{mM})$ & E/Z-VOx & $Z$-PAOx \\
\hline none & & 100 & 100 \\
$\mathrm{Cu}^{+}, \mathrm{Cu}^{2+}, \mathrm{Co}^{2+}, \mathrm{Zn}^{2+}, \mathrm{Cd}^{2+}$ & 1 & $11.5-72.6$ & $13.6-63.8$ \\
$\mathrm{Fe}^{2+}$ & 0.1 & $204-368$ & $172-986$ \\
$\mathrm{Fe}^{3+}$ & 1 & 292 & 534 \\
& 1 & 835 & 1,580 \\
$\mathrm{Hg}^{2+}$ & 1 & $529^{b}$ & $632^{b}$ \\
$\mathrm{Sn}^{2+}$ & 0.1 & 71.6 & 69.7 \\
$\mathrm{Tiron}^{2+}$ & 1 & 39.9 & 29.0 \\
& 1 & 80.6 & 5.31 \\
phenylhydrazine & 0.1 & 103 & 64.0 \\
& 1 & 72.1 & 1.60 \\
$\mathrm{~K}_{3}\left[\mathrm{Fe}(\mathrm{CN})_{6}\right]$ & 0.1 & 100 & 26.7 \\
vitamin K & 0.1 & 196 & 291 \\
duroquinone & 0.1 & $136^{b}$ & $163^{b}$ \\
& 1 & 263 & 378 \\
& 1 & 135 & 167
\end{tabular}

${ }^{a}$ The enzyme activity for both substrates was partially $(30-80 \%)$ inhibited by $1 \mathrm{mM}$ of metal ions such as $\mathrm{Al}^{3+}, \mathrm{V}^{+}, \mathrm{As}^{2+}, \mathrm{Nb}^{5+}, \mathrm{Ag}^{+}$, $\mathrm{Hg}^{2+}, \mathrm{Tl}^{2+}, \mathrm{Pb}^{2+}$, and penicillamine, thioglycerol, vitamin $\mathrm{K}_{1}$, vitamin $\mathrm{K}_{12}$, 8-hydroxyquinoline, o-phenanthroline, iodoacetate, dithiobis (4nitrobenzoic acid), $p$-chloromercuribenzoate, diphenylhydanthoin, glutathione, glutathione disulfide, phenazinemethosulfate, trimethylhydroquinone, phenylenediamine, tetramethylphenylenediamine, dimethylphenylenediamine, guaiacol, pyrogallol, miconazole, and nitroblue tetrazolium. No inhibitory effect was seen in the presence of $0.01-1$ $\mathrm{mM}$ of other metal ions, EDTA, EGTA, bipyridyl, $N$-ethylmaleiimide, phenymethanesulfonyl fluoride, $\mathrm{KCN}, \mathrm{NH}_{2} \mathrm{OH}, \mathrm{NaN}_{3}$, hydrazine, D-cycloserine, barbital, or avidine. ${ }^{b}$ Activity measurements were done in the absence of $\mathrm{Na}_{2} \mathrm{~S}$.

entire gene with its flanking sequence. The nucleotide sequence analysis of the total 11.6-kb DNA revealed an ORF (orf2) for the enzyme with a start codon ATG, a stop codon TGA, and a potential ribosome-binding site (AGGGAG) just before the start codon. The predicted protein was translated as 353 amino acids, with an amino acid sequence identical to that obtained by $N$-terminal sequencing (Figure 4). The $M_{\mathrm{r}}$ of the protein was estimated to be 39892 , which agree with the calculated $M_{\mathrm{r}}$ of the subunit (42000). The ORF was thus named oxd as the structural gene for the enzyme. The predicted polypeptide (OxdRG) encoded by oxd showed $30.3 \%$ identity with OxdB (Figure 5) and $97.8 \%$ identity to the predicted polypeptide containing 137 amino acids encoded by an unidentified part of the gene that was located just upstream of the regulator 2 gene in the NHase-amidase operon in the iron-type NHase producer Rhodococcus sp. N-771 (35). No significant similarity was found between OxdRG and the gene products for other known proteins in the databases.

Analysis of the Flanking Region of the oxd Gene. Further sequencing of the flanking $5^{\prime}$-regions of $o x d$ revealed another ORF (orfa), which consisted of 978 bp starting with an ATG initiation codon located 1182 bp upstream from the oxd start codon. The deduced amino acid sequence of orfa showed significant similarity to the following transcriptional regulatory (DNA-binding) proteins: transcription factor nitR (26.1\%), which regulates nitrilase in $R$. rhodochrous $\mathrm{J}-1$; a transcriptional regulator (25.5\%) from Bradyrhizobium japonicum; a probable DNA-binding regulatory protein (24.6\%) from Streptomyces coelicolor; and a putative araC family regulatory protein $(23.9 \%)$ from $S$. coelicolor A3(2). The protein encoded by orfa could be a regulatory protein, although its function is not yet clear. Upstream of orfa, an incomplete ORF (orfc) without a stop codon was present in a reverse orientation. The deduced amino acid sequence of the ORF showed remarkable similarity to acy-CoA ligase (synthase), such as fatty acid CoA ligase of Bacillus cereus (AAP07877, 33\% identity), feruloyl CoA synthase of Amycolatopsis sp. (Q9EY88, 34\%), and acyl-CoA synthase of Streptomyces avermitilis (BAC68086, 35\%). As shown in Figure 6 and Table 4, the $3^{\prime}$-flanking region of oxd demonstrated the presence of genes for NHase and its regulatory proteins and amidase having high identity as in Rhodococcus sp. N-771 (36) and Rhodococcus sp. AJ270. The deduced amino acid sequences of $\operatorname{orf} 3,4,5,6,7$, and 8 displayed $82.8,85.9,96.4,98.6,98.6$, and $73.2 \%$ identity to those of NHase regulator 2, NHase regulator 1, amidase, NHase $\alpha$-subunit, NHase $\beta$-subunit, and NHase activator of Rhodococcus sp. N-771, respectively. The deduced amino acid sequences of orf4, 5, 6, 7, and 8 displayed 98.0, 96.4, 98.6, 98.6, and $98.0 \%$ identity with those of Rhodococcus sp. AJ270, respectively. We therefore changed the names of orf 3, 4, 5, 6, 7, and 8 to $n h r 2, n h r 1$, ami, nha1, nha2, and $n h r 3$, respectively. Immediately downstream of the activator gene $n h r 3$ there is a 912-bp orfb. It shared more than $91 \%$ sequence identity to a part of a hypothetical protein gene (302-bp) of Rhodococcus sp. AJ270. Promoter-like sequences were found upstream of $o r f a, n h r 2$, and ami (data not shown).

Overexpression and Characterization of Recombinant $O x d R G$. The complete oxd amplified by PCR from pOxdRGHII, with a modified Shine-Dalgarno sequence (AGGAGG), was inserted into pUC19 so that the enzyme was under the control of the lac promoter. The resulting plasmid (pOxdRGP9) was introduced into E. coli JM109 cells. The activity shown by $E$. coli cells containing pOxdRGP9 was about 300 units/liter culture in Terrific medium using Z-PAOx as the substrate; it was 15 times higher than that of $R$. globerulus A-4 cells cultured in TGY medium with $E$-3-PyOx as the inducer.

The recombinant OxdRG was purified through a 9-step purification procedure (Supporting Information, Table S1). It was purified 14.9 -fold with a yield of $4.75 \%$ from the cellfree extract by measuring activity with Z-PAOx as the substrate. The purified recombinant OxdRG showed a single band on SDS-PAGE and a single peak on the G-3000 SW column in agreement with the $M_{\mathrm{r}}$ of wild-type OxdRG. The heme content of the recombinant enzyme determined from the spectrum of its pyridine hemochromogen was calculated to be $0.35 \mathrm{~mol}$ of heme/mol of enzyme, the same as wildtype OxdRG. Recombinant OxdRG was activated by several reducing reagents similar to wild-type OxdRG. The specific activity of recombinant OxdRG for Z-PAOx was 2.18 units/ $\mathrm{mg}$ which was about 24.8-fold higher than that of wild-type (0.088 unit/mg of protein) in the presence of $1 \mathrm{mM} \mathrm{Na} 2 \mathrm{~S}$. The effect of $\mathrm{Na}_{2} \mathrm{~S}$ at the various stages of purification of the recombinant enzyme was similar to its effect on wildtype OxdRG (data not shown).

\section{DISCUSSION}

To understand the relationship between aldoxime dehydratase and NHase/amidase, we purified and characterized 
HinCII

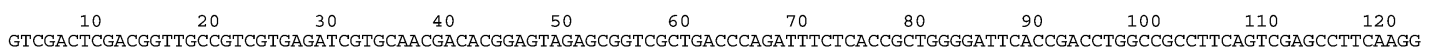
$\begin{array}{lllllllllll}130 & 140 & 150 & 160 & 170 & 180 & 190 & 200 & 210 & 220 & 230\end{array}$

CGGAATTCGGGATCAGCCCGCGGCGGTACCGGTCGCAAGCAGCGGCCCCCACAAGTACTACCCGCTGATCTGTAACATCTTCGGACACTTACCCATTGAACATGGTGTTCAAAATTTTCT

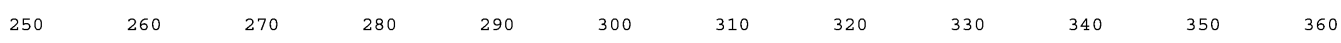

GTCGCCGAAGCGTATCCACAATTCTTGGCACGGTAGGCCAAGCATCGGGCGCTGACGGCCAAGTTTGCTCGGCTGAGCGGGCGTAGATTTTCGGCACGGCGTTGCCAAGTGCCAGGCACC $\begin{array}{lllllllllll}370 & 380 & 390 & 400 & 410 & 420 & 430 & 440 & 450 & 460 & 470\end{array}$ CGATTCGACCACCTACATCACAGGGAGCACTCATGGAATCTGCAATCGGCGAACACCTTCAATGCCCGCGCACTCTGACCAGGCGGGTTCCGGATACCTATACGCCACCGTTTCCCATGT

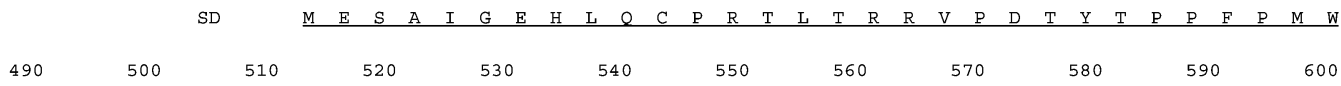
GGGTCGGCGCGCAGACGACACATTGCACCAAGTCGTGATGGGCTATCTCGGCGTGCAGTTCCGCGGCAGGATCAGCGCCCGGCAGCACTGCGGCGATGCGGGATATCGTCGCCGGCT

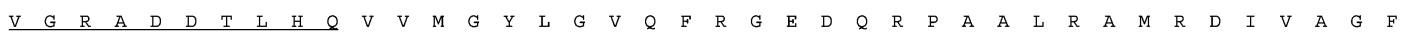
$\begin{array}{lllllllllll}610 & 620 & 630 & 640 & 650 & 660 & 670 & 680 & 690 & 700 & 710\end{array}$

TCGACTTGCCGGACGGACCGGCACACCACGATCTCACCCATCACATCGACAACCAGGGCTACGAGAACCTGATCGTGGTCGGTTACTGGAAAGATGTTTCTTCCCAACATCGTTGGGGCA

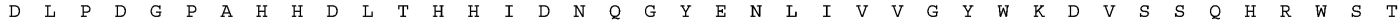
$\begin{array}{lllllllllll}730 & 740 & 750 & 760 & 770 & 780 & 790 & 800 & 810 & 820 & 830\end{array}$ CATCACCTCCAGTGTCCTCCTGGTGGGAGTCCGAAGACCGCCTGTCGGACGGATTGGGGTTCTTCCGCGAGATCGTGGCACCGAGAGCCGAACAATTCGAAACGCTCTACGCGTTCCAAG

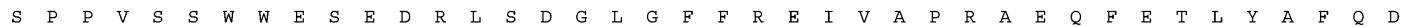
$\begin{array}{lllllllllll}850 & 860 & 870 & 880 & 890 & 900 & 910 & 920 & 930 & 940 & 950\end{array}$ ACGACCTCCCCGGGGTGGGAGCTGTCATGGACGGTGTCAGCGGCGAAATCAACGAGCACGGCTACTGGGGTTCGATGCGCGAGCGGTTTCCGATCTCCCAAACCGACTGGATGCAGGCCT

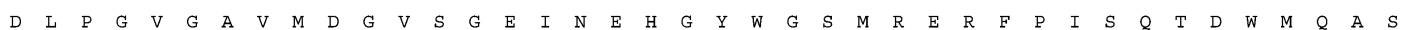

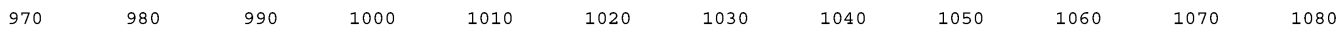

CGGGCGAACTGCGGGTCGTCGCCGGTGACCCCGCCGTAGGTGGACGCGTAGTAGTGCGGGGACACGACAACATCGCACTGATCAGGTCCGGGCAGGACTGGGCCGACGCGGAAGCAGACG

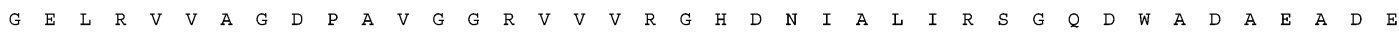

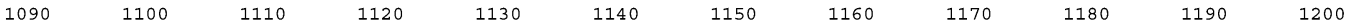
AGCGCAGCCTCTACCTGGACGAAATCCTGCCCACTCTTCAATCGGGCATGGACTTCCTCCGCGACAACGGCCCGGCCGTCGGGTGCTACAGCAACCGATTCGTACGCAATATCGACATCG $\begin{array}{lllllllllllllllllllllllllllllllllllllllllllll}R & S & L & Y & L & D & E & I & L & P & T & L & Q & S & G & M & D & F & L & R & D & N & G & P & A & V & G & C & Y & S & N & R & F & V & R & N & I & D & I & D\end{array}$

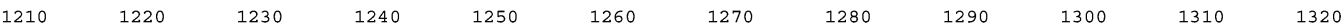

ACGGAAACTTCCTCGACTTGAGCTACAACATCGGCCACTGGGCCTCCCTCGACCAACTCGAACGGTGGTCGGAATCCCACCCGACCCATCTACGGATCTTCACGACGTTCTTCCGGGTGG

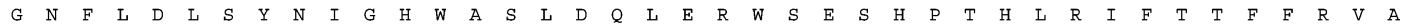

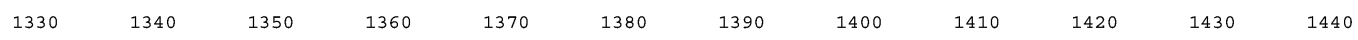

CCGAGGGCCTGTCGAAATTGCGTCTCTACCATGAGGTCTCGTATTCGATGCCGCCGATCAGCTCTACGAGTACATCAATTGCCATCCCGGGACCGGAATGCTGCGCGACGCGGTGATCA

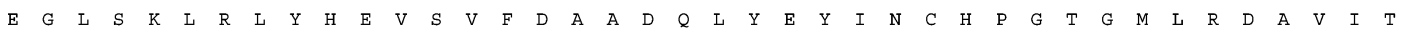
$\begin{array}{lllllll}1450 & 1460 & 1470 & 1480 & 1490 & 1500 & 1510\end{array}$

CCGCCGAGCACTGACCGAAGTCGCCGGAAATCTTCGGCCACATTCTTTCCCTCGGAGGCAACTCGAGATATGTT

A E H * HincII

FIGURE 4: Nucleotide and predicted amino acid sequences of the aldoxime dehydratase gene (oxd) from R. globerulus A-4. The underlined amino acid sequence corresponds with that of the $N$-terminal peptide of OxdRG. The putative ribosome-binding sequence is shown in italics. An asterisk indicates the stop codon.

an aldoxime dehydratase OxdRG from $R$. globerulus A-4 isolated from soil, in which NHase/amidase were present together with the aldoxime dehydratase. Table 5 shows a comparison of the properties of OxdRG and OxdB. Although both enzymes contain heme $b$ as a prosthetic group and have a similar optimum $\mathrm{pH}$ and temperature, some differences are apparent. OxdRG has a dimeric structure, but $\mathrm{OxdB}$ is a monomer. Wild-type OxdRG exhibits a lower Z-PAOx dehydration rate $(0.088$ unit $/ \mathrm{mg})$ than $\mathrm{OxdB}(8.5$ units $/ \mathrm{mg})$ (18); however, the rate for the recombinant OxdRG is similar (2.2 units $/ \mathrm{mg}$ ). The substrate specificity of OxdRG is broader than that of $\mathrm{OxdB}$. Aliphatic aldoximes are more effective substrates than arylalkyl aldoximes for OxdRG, and aromatic aldoximes are also dehydrated. Moreover, alkyl- and arylalkyl-aldoximes substituted at their $\alpha$-position, such as E/Zisobutyraldoxime and E/Z-2-PPOx, are acceptable to OxdRG, although the activity is significantly diminished compared with the corresponding unsubstituted aldoximes (Table 2). Due to a wide substrate specificity, direct use of whole recombinant $E$. coli cells overexpressing OxdRG may be a useful biocatalyst for the production of various nitriles from the corresponding aldoximes. Since OxdRG can act on 2-PPOx or mandelaldoxime, the possibility exists for the production of optically active nitriles from aldoximes. 


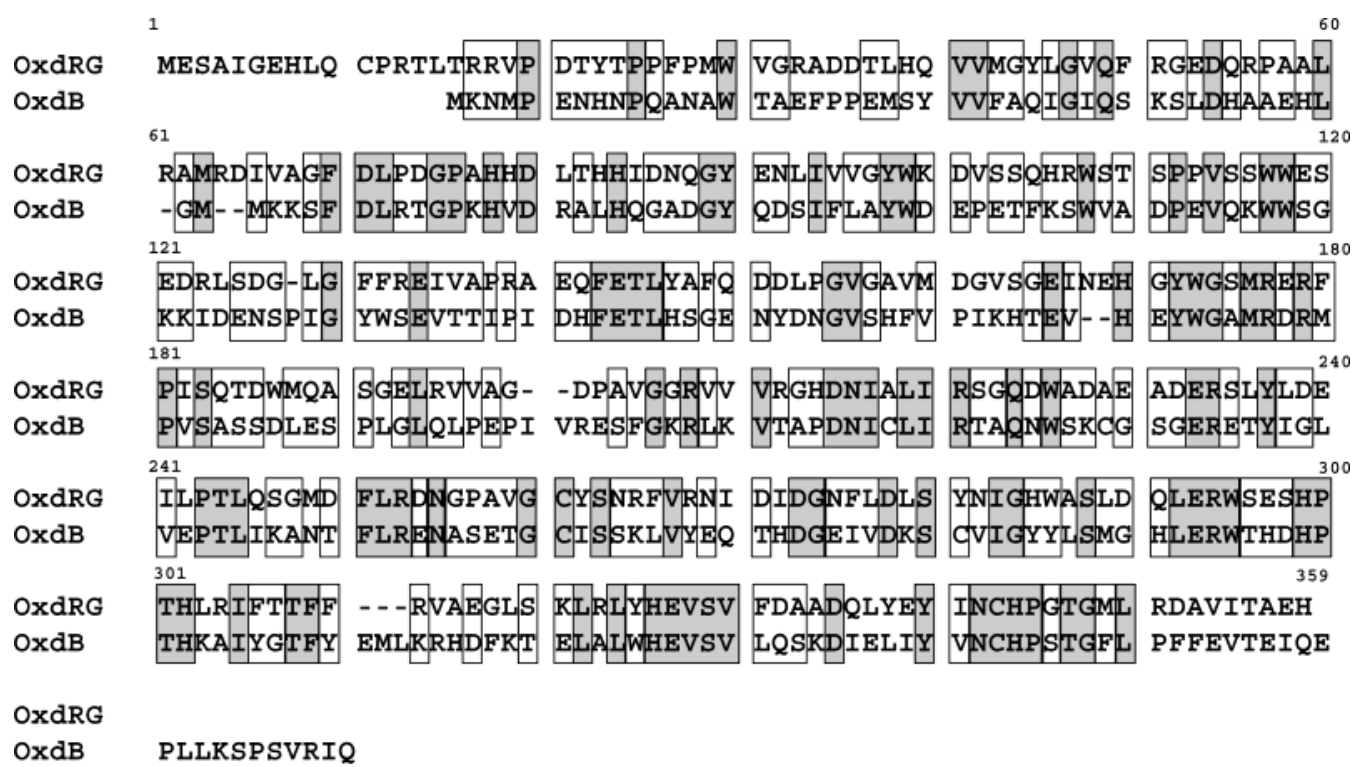

FIGURE 5: Alignment of the deduced amino acid sequences of the aldoxime dehydratases from R. globerulus A-4 (OxdRG) with Bacillus sp. OxB-1 (OxdB) (GenBank/EBI, AB028892). The alignment was performed with the ClustalW method. Gaps denoted by dashes were inserted to obtain maximum homology. Gray and open boxes show identical and similar residues between the sequences, respectively.
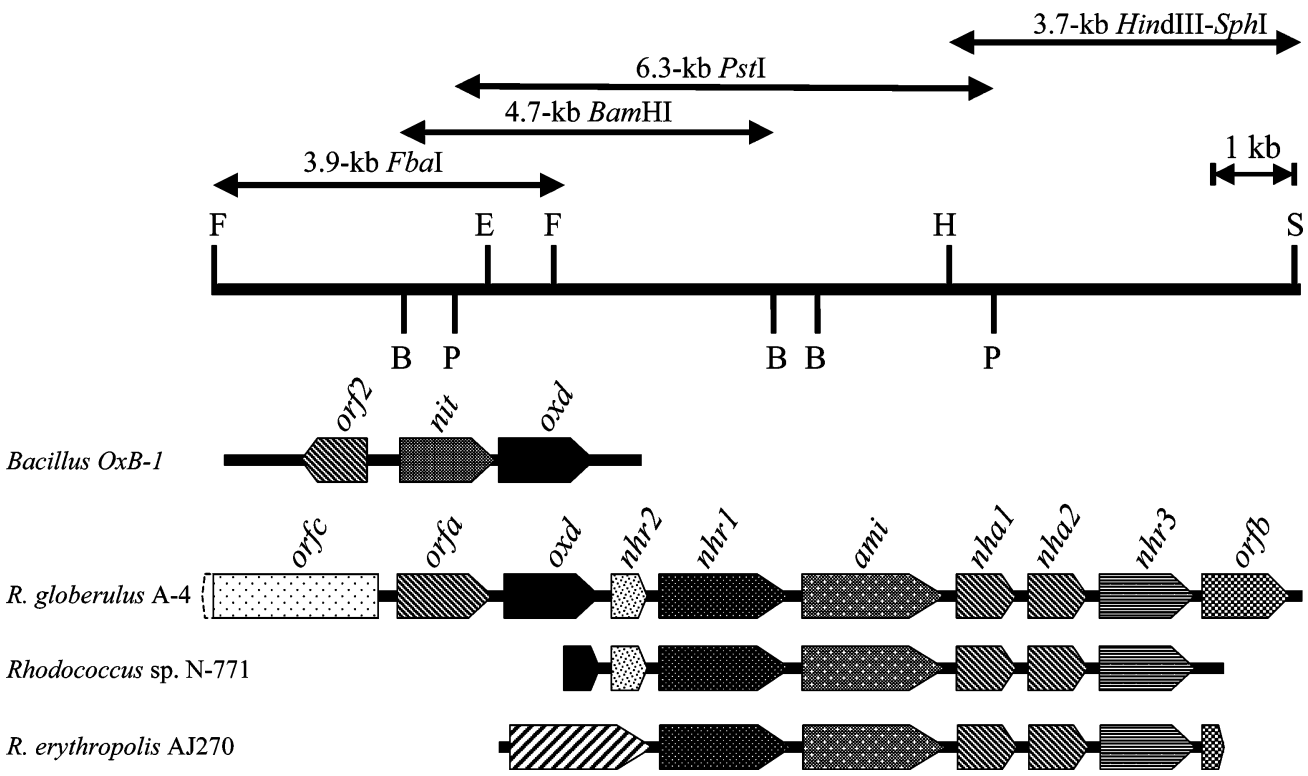

FIGURE 6: Genetic organization of the sequenced 11.6-kb DNA fragment and comparison of the gene cluster from R. globerulus A-4 with that of Bacillus sp. OxB-1, Rhodococcus sp. N-771, and Rhodococcus sp. AJ270. Four fragments (3.9-kb FbaI, 4.7-kb BamHI, 6.3-kb PstI, and 3.7-kb HindIII-SphI fragments) are also indicated. The positions and orientations of the different ORFs detected within the locus are shown by large arrows. F, FbaI; E, EcoRI; B, BamHI; P, PstI; H, HindIII; S, SphI.

The purified OxdRG activity was greatly enhanced by reducing reagents, such as $\mathrm{Na}_{2} \mathrm{~S}, \mathrm{Na}_{2} \mathrm{~S}_{2} \mathrm{O}_{4}$, and some sulfhydryl compounds. The activity was further enhanced by $\mathrm{Fe}^{2+}$ as well as OxdB (18). On the basis of these observations, it is concluded that OxdRG and $\mathrm{OxdB}$ both require reduction to stimulate the reaction process. Distinct from OxdB activity, however, OxdRG activity was not enhanced under anaerobic conditions. Oxidized irons $\left(\mathrm{Fe}^{3+}\right.$ and $\mathrm{K}_{3-}$ $\left.\left[\mathrm{Fe}(\mathrm{CN})_{6}\right]\right)$ also enhanced activity both in the presence and absence of $\mathrm{Na}_{2} \mathrm{~S}$, but their effect on the activity is unclear. The mechanisms for the effect of some metal ions, $\mathrm{Cu}^{+}$, $\mathrm{Cu}^{2+}, \mathrm{Co}^{2+}, \mathrm{Zn}^{2+}$, and $\mathrm{Cd}^{2+}$, which act as both activators and inhibitors depending on their concentrations, are also not understood. The fact that phenylhydrazine and Tiron inhibited Z-PAOx dehydration but not E/Z-VOx dehydration suggests that they might inhibit the reaction by interfering with the binding of substrate by their aromatic ring. The enhancement of the enzyme activity by flavins, vitamin $\mathrm{K}_{3}$, duroquinone, and sulfite ion suggests that the enzyme requires an electron acceptor during the reaction progress. Partially purified indoleacetaldoxime hydrolyase (EC 4.2.1.29) is activated by PLP, ascorbic acid, and dehydroascorbic acid (37), but OxdRE is not activated by the compounds, suggesting that OxdRG is different from indoleacetaldoxime hydrolyase.

The heme content of the purified wild-type and recombinant OxdRG was low as it was for OxdB. It is still unclear whether the heme was lost during the purification or the enzyme was originally produced with a low heme content. Also, the actual role of the reducing reagents and electron acceptors in the enzyme reaction is little understood. The crystal structures of the active site of both enzymes may help 
Table 4: ORFs Deduced by Sequencing Analysis of the 11.6-kb Fragment from R. globerulus A-4 and Their Corresponding Gene Products and Related Gene Products

\begin{tabular}{|c|c|c|c|c|c|c|c|}
\hline \multirow{2}{*}{$\begin{array}{l}\text { gene } \\
\text { or orf }\end{array}$} & \multirow[b]{2}{*}{ function } & \multirow{2}{*}{$\begin{array}{l}\text { gene } \\
\text { product } \\
(\mathrm{aa})^{a}\end{array}$} & \multirow[b]{2}{*}{ gene } & \multicolumn{4}{|c|}{ related gene and its product } \\
\hline & & & & function & organism & identity i\% j & $\overline{\text { accession no. }}$ \\
\hline \multirow[t]{4}{*}{1 orfa } & $\begin{array}{l}\text { putative regulatory } \\
\text { protein }\end{array}$ & 326 & nitR & transcription factor $n i t R$ & R. rhodochrous $\mathrm{J} 1$ & 26.1 & JC6117 \\
\hline & & & & transcriptional regulator & Bradyrhizobium japonicum & 25.5 & AP005958 \\
\hline & & & & $\begin{array}{l}\text { probable DNA-binding } \\
\text { regulatory protein }\end{array}$ & Streptomyces coelicolor & 24.6 & T36475 \\
\hline & & & $\operatorname{araC}$ & $\begin{array}{l}\text { putative } a r a C \text { family } \\
\text { regulatory protein }\end{array}$ & S. coelicolor A3(2) & 23.9 & AL939112 \\
\hline \multirow[t]{2}{*}{2 oxd } & $\begin{array}{l}\text { aldoxime } \\
\text { dehydratase }\end{array}$ & 353 & oxd & $\begin{array}{l}\text { phenylacetaldoxime } \\
\text { dehydratase }\end{array}$ & Bacillus sp. OxB-1 & 30.3 & AB028892 \\
\hline & & & & undefined & Rhodococcus sp. N-771 & $97.8(137)^{b}$ & AB016078 \\
\hline \multirow[t]{3}{*}{$3 n h r 2$} & NHase regulator2 & 122 & $n h r 2$ & NHase regulator2 & Rhodococcus sp. N-771 & 82.8 & AB016078 \\
\hline & & & $n h 1 D$ & NHase regulator2 & R. rhodochrous $\mathrm{J} 1$ & 41.8 & D67028 \\
\hline & & & & transposase & R. erythropolis AJ 270 & $95.4(65)$ & RER490527 \\
\hline \multirow[t]{2}{*}{$4 n h r 1$} & NHase regulator1 & 410 & $n h r l$ & NHase regulator 1 & R. erythropolis AJ 270 & 98.0 & RER490527 \\
\hline & & & $n h r l$ & NHase regulator 1 & Rhodococcus sp. N-771 & 85.9 & AB016078 \\
\hline \multirow[t]{3}{*}{$5 \mathrm{ami}$} & amidase & 521 & ami & amidase & Rhodococcus sp. N-771 & 96.4 & AB016078 \\
\hline & & & ami & amidase & Rhodococcus sp. N-774 & 96.4 & X54074 \\
\hline & & & ami & amidase & R. erythropolis AJ270 & 96.4 & RER490527 \\
\hline \multirow[t]{3}{*}{6 nhal } & NHase $\alpha$-subunit & 207 & nhal & NHase $\alpha$-subunit & Rhodococcus sp. N-771 & 98.6 & AB016078 \\
\hline & & & nhal & NHase $\alpha$-subunit & Rhodococcus sp. N-774 & 98.6 & X54074 \\
\hline & & & nha & NHase $\alpha$-subunit & R. erythropolis $\mathrm{AJ} 270$ & 98.6 & RER490527 \\
\hline \multirow[t]{3}{*}{7 nha2 } & NHase $\beta$-subunit & 212 & nha2 & NHase $\beta$-subunit & Rhodococcus sp. N-771 & 98.6 & AB01607 \\
\hline & & & nha2 & NHase $\beta$-subunit & Rhodococcus sp. N-774 & 98.6 & X54074 \\
\hline & & & $n h b$ & NHase $\beta$-subunit & R. erythropolis $\mathrm{AJ} 270$ & 98.6 & RER490527 \\
\hline \multirow[t]{2}{*}{$8 n h r 3$} & NHase activator & 399 & nha3 & NHase activator & R. erythropolis AJ 270 & 98.0 & RER490527 \\
\hline & & & nha3 & NHase activator & Rhodococcus sp. N-771 & 73.2 & AB016078 \\
\hline 9 orfb & hypothetical protein & 304 & orfe & hypothetical protein & R. erythropolis $\mathrm{AJ} 270$ & $43.6(101)$ & RER490527 \\
\hline
\end{tabular}

${ }^{a}$ aa, amino acid. ${ }^{b}$ The number in parentheses indicates the partial deduced amino acid sequence of the gene product that has been used for comparison.

Table 5: Comparison of the Properties of Aldoxime Dehydratases from R. globerulus A-4 and Bacillus sp. OxB-1

\begin{tabular}{|c|c|c|c|c|}
\hline \multirow[b]{2}{*}{ property } & \multicolumn{4}{|c|}{ value with enzyme from } \\
\hline & \multicolumn{2}{|l|}{ R. globerulus A-4 } & \multicolumn{2}{|l|}{ Bacillus sp. OxB-1 } \\
\hline $\begin{array}{l}\text { molecular weight } \\
\text { (sequencing) }\end{array}$ & 39,892 & & 40,018 & \\
\hline (subunit) & 42,000 & & 40,000 & \\
\hline (native) & 76,200 & & 42,000 & \\
\hline no. of subunits & 2 & & 1 & \\
\hline optimum & $8.0(\mathrm{KPB})$ & & $7.0(\mathrm{KPB})$ & \\
\hline $\begin{array}{l}\mathrm{pH} \\
\text { temp }\end{array}$ & $30^{\circ} \mathrm{C}$ & & $30^{\circ} \mathrm{C}$ & \\
\hline stable & $6.0-9.5$ & & $6.5-11.5$ & \\
\hline $\mathrm{pH}$ & & & & \\
\hline temp & $<40^{\circ} \mathrm{C}$ & & $<45^{\circ} \mathrm{C}$ & \\
\hline substrate specificity & aryl-, arylalkyl-, alkylaldoxime & & arylalkyl-, alkylaldoxime & \\
\hline prosthetic group & heme $b$ & & heme $b$ & \\
\hline activator & $\mathrm{FMN}, \mathrm{Fe}^{2+}, \mathrm{Sn}^{2+}, \mathrm{Na}_{2} \mathrm{SO}_{3}, \mathrm{Na}_{2} \mathrm{~S}$, vitamin $\mathrm{K}_{3}$ & & FMN $, \mathrm{Fe}^{2+}, \mathrm{Sn}^{2+}, \mathrm{Na}_{2} \mathrm{SO}_{3}$ & \\
\hline $\begin{array}{l}\text { inhibitor } \\
\text { (cations) }\end{array}$ & $\begin{array}{l}\mathrm{Co}^{2+}, \mathrm{Zn}^{2+}, \mathrm{Cd}^{2+}, \mathrm{Cu}^{+}, \mathrm{Cu}^{2+}, \mathrm{Ag}^{+}, \\
\quad \mathrm{Hg}^{2+}, \mathrm{Ti}^{+}, \mathrm{As}^{3+}\end{array}$ & & $\mathrm{Cu}^{+}, \mathrm{Cu}^{2+}, \mathrm{Ag}^{+}, \mathrm{Hg}^{2+}$ & \\
\hline (chemical compounds) & electron donors and carriers & & $\begin{array}{l}\text { EDTA, 8-hydroxyquinoline } \\
\text { tetramethylphenylenediamine }\end{array}$ & \\
\hline$K_{\mathrm{m}}(\mathrm{mM})$ and $V_{\max }$ (units/mg) value for & $K_{\mathrm{m}}$ & $V_{\max }$ & $K_{\mathrm{m}}$ & $V_{\max }$ \\
\hline Z-PAOx & 1.40 & 0.140 & 0.872 & 19.5 \\
\hline$Z-3-P P O x$ & 2.31 & 0.392 & 1.36 & 14.3 \\
\hline E/Z-indoleacetaldoxime & 3.91 & 0.281 & 2.40 & 5.42 \\
\hline$E / Z-2-P P O x$ & 11.9 & 0.810 & no reaction & \\
\hline$E$-PyOx & 20.0 & 0.065 & no reaction & \\
\hline E/Z-cyclohexanecarboxaldehyde oxime & 1.13 & 0.386 & no reaction & \\
\hline E/Z-n-butyraldoxime & 1.73 & 0.689 & 11.1 & 9.49 \\
\hline E/Z-isobutyraldoxime & 5.54 & 0.041 & no reaction & \\
\hline$E / Z$-n-capronaldoxime & 2.94 & 1.66 & 6.12 & 32.3 \\
\hline E/Z-isocapronaldoxime & 6.76 & 1.32 & 2.98 & 10.1 \\
\hline
\end{tabular}

to explain the mechanism of the reaction. Interestingly, the specific activity of the recombinant OxdRG for PAOx was 25 times that of the wild-type, although the heme contents of the two were nearly the same. Since the effect of $\mathrm{Na}_{2} \mathrm{~S}$ on enzyme activity was similar in the wild type and recombinant OxdRGs, it is possible to consider that an 
unknown cofactor was lost from wild-type OxdRG during the purification and that the cofactor property could not be restored by the addition of $\mathrm{Na}_{2} \mathrm{~S}$. However, the actual reasons for the observations are not clear at the present time.

Sequence analysis of the 11.6-kb DNA fragment revealed the presence of at least nine complete open reading frames (orfa, oxd, nhr2, nhr1, ami, nha1, nha2, nhr3, and orfb). These genes encode the proteins involved in aldoxime metabolism, a combination of aldoxime dehydratase, NHase, and amidase, together with the regulatory proteins. An aldoxime dehydratase gene homologue in Rhodococcus sp. $\mathrm{N}-771$ is likely to be located just upstream of the regulator 2 gene, given its high sequence similarity to a part of oxd (unpublished data). It is anticipated that the gene cluster regulating aldoxime metabolism in Rhodococcus sp. N-771 might be similar to that of $R$. globerulus $\mathrm{A}-4$. The coexistence of the structural genes for OxdRG, amidase, and NHase, together with regulatory proteins, favors the expression of three enzymes in $R$. globerulus A-4, suggesting that the enzymes may be related and coexist in a single metabolic pathway for aldoxime catabolism. Rhodococcus sp. AJ270 has a similar gene assembly and shows high homology to R. globerulus A-4 and Rhodococcus sp. N-771, except for a transposase gene which is located just upstream of the NHase regulator 1 gene. The deduced 65 -amino acid sequence of $n h r 2$ of $R$. globerulus A-4 displayed $95.4 \%$ identity with that of transposase. Since $R$. globerulus A-4, Rhodococcus sp. N-771, and Rhodococcus sp. AJ270 probably evolved from the same ancestor, an evolutionary change in Rhodococcus sp. AJ270 was the insertion of the transposon into the aldoxime/nitrile metabolic operons.

Even though it has not been purified or characterized yet, the NHase encoded by the genes present in the 3'-flanking region of oxd may preferentially act on aliphatic nitriles because NHase of Rhodococcus sp. N-771 encoded by nhal and nha2, which showed high identity with the NHase in $R$. globerulus A-4, prefers aliphatic nitriles to aromatic nitriles (38). We conclude that OxdRG, in combination with NHase and amidase, plays a significant role in the metabolism of alkylaldoxime, according to the enzymological and genetic evidence.

Studies are under way to clarify the existence of biosynthetic pathways of aldoximes from amino acids in microorganisms similar to those in plants and their evolutionary relationships.

\section{SUPPORTING INFORMATION AVAILABLE}

Table of purificaion of the recombinant aldoxime dehydratase from E. coli JM109/pOxDRGP9. This material is available free of charge via the Internet at http://pubs.acs.org.

\section{REFERENCES}

1. Sibbesen, O., Koch, B., Rouzé, P., Møller, B. L., and Halkier, B. A. (1995) in Amino Acids and Their Derivatives in Higher Plants (Wallsgrove, R. M., Ed.) pp 227-241, Cambridge University Press, Cambridge.

2. Andersen, M. D., Busk, P. K., Svendsen, I., and Møller, B. L. (2000) J. Biol. Chem. 275, 1966-1975.

3. Nielsen, J. S., and Møller, B. L. (2000) Plant Physiol. 122, 13111321.
4. Bak, S., Tax, F. E., Feldmann, K. A., Galbraith, D. A., and Feyereisen, R. (2001) Plant Cell. 13, 101-111.

5. Bak, S., Olsen, C. E., Halkier, B. A., and Møller, B. L. (2001) Plant Physiol. 123, 1437-1448.

6. Bak, S., and Feyereisen, R. (2001) Plant Physiol. 127, 108-118.

7. Hansen, C. H., Du, L.-C., Naur, P., Olsen, C. E., Axelsen, K. B., Hick, A. J., Pickett, J. A., and Halkier, B. A. (2001) Biol. Chem. 276, 24790-24796.

8. Yamada, H., Asano, Y., Hino, T., and Tani, Y. (1979) J. Ferment. Technol. 57, 8-14.

9. Asano, Y., Yasuda, T., Tani, Y., and Yamada, H. (1982) Agric. Biol. Chem. 46, 1183-1189.

10. Asano, Y., Tani, Y., and Yamada, H. (1980) Agric. Biol. Chem. 44, 2251-2252.

11. Asano, Y., Fujishiro, K., Tani, Y., and Yamada, H. (1982) Agric. Biol. Chem. 46, 1165-1174.

12. Asano, Y. (1991) Nippon Nogeikagaku Kaishi 65, 1617-1626.

13. Yamada, H., and M. Kobayashi. (1996) Biosci. Biotechnol. Biochem. 60, 1391-1400.

14. Hann, E. C., Eisenberg, A., Fager, S. K., Perkins, N. E., Gallagher, F. G., Cooper, S. M., Gavagan, J. E., Stieglitz, B., Hennessey, S. M., and DiCosimo, R. (1999) Bioorg. Med. Chem. 7, 2239-2245.

15. Asano, Y., and Kato, Y. (1998) FEMS Microbiol. Lett. 158, 185190.

16. Kato, Y., Ooi, R., and Asano, Y. (1998) Arch. Microbiol. 170, $85-90$.

17. Asano, Y. (2002) J. Biotechnol. 94, 65-72.

18. Kato, Y., Nakamura, K., Sakiyama, H., Mayhew, S. G., and Asano, Y. (2000) Biochemistry, 39, 800-809.

19. Kato, Y., and Asano, Y. (2003) Protein Express. Purif. 28, 131139

20. Xie, S.-X., Kato, Y., and Asano, Y. (2001) Biosci. Biotechnol. Biochem. 65, 2666-2672.

21. Kato, Y., Ooi, R., and Asano, Y. (2000) Appl. Environ. Microbiol. $66,2290-2296$

22. Kato, Y., Ooi, R., and Asano, Y. (1999) J. Mol. Catal. B. Enzymatic 6, 249-256.

23. Asano, Y., Itoh, H., Dairi, T., and Kato, Y. (1996) J. Biol. Chem. 271, 30256-30262.

24. Davis, B. J. (1964) Ann. New York Acad. Sci. 121 (Part 2), 404427.

25. Laemmli, U. K. (1970) Nature 227, 680-685.

26. Goodhew, C. F., Brown, K. R., and Pettigrew, G. W. (1986) Biochim. Biophys. Acta. 852, 288-294.

27. Appleby, C. A., and Morton, R. K. (1959) Biochem. J. 73, 539550.

28. Siegel, L. M., Murphy, M. J., and Kamin, H. (1973) J. Biol. Chem. $248,251-264$

29. Lechevalier, H. A. (1986) Nocardioforms in Bergey's Manual of Systematic Bacteriology (Sneath, P. H. A., Ed.) Vol. 2, pp 14581506, Williams and Willkins, Baltimore and London.

30. Miller, L. T. (1982) J. Clin. Microbiol. 16, 54-586.

31. Nagamune, T., Kurata, H., Hirata, M., Honda, J., Koike, H., Ikeuchi, M., Inoue, Y., Hirata, A., and Endo, I. (1990) Biochem. Biophys. Res. Commun. 168, 437-442.

32. Sanger, F. S., Nicklen, S., and Coulson, A. R. (1977) Proc. Natl. Acad. Sci. U.S.A. 74, 5463-5467.

33. Pearson, W. R., and Lipman, D. J. (1988) Proc. Natl. Acad. Sci. U.S.A. 85, 2444-2448.

34. Altschul, S. F., Gish, W., Miller, W., Myers, E. W., and Lipman, D. J. (1990) J. Mol. Biol. 215, 403-410.

35. Thompson, J. D., Higgins, D. G., and Gibson, T. J. (1994) Nucleic Acid Res. 22, 4673-4680.

36. Nojiri, M., Yohda, M., Odaka, M., Matsushita, Y., Tsujimura, M., Yoshida, T., Dohmae, N., Takio, K., and Endo, I. (1999) J. Biochem. 125, 696-704.

37. Shukla, P. S., and Mahadevan, S. (1970) Arch. Biochem. Biophys. 137, 166-174

38. Banerjee, A., Sharma, R., and Banerjee, U. C. (2002) Appl. Microbiol. Biotechnol. 60, 33-44.

BI035092U 